Original Article

\title{
The Serra Spanish mackerel fishery (Scomberomorus brasiliensis - Teleostei) in Southern Brazil: the growing landings of a high trophic level resource
}

\author{
A pesca da cavala, Scomberomorus brasiliensis (Teleostei), no sul do Brasil: \\ o aumento nos desembarques de um recurso de alto nível trófico
}

\author{
P. T. C. Chaves ${ }^{a^{*}}$ (1) and P. O. Birnfeld ${ }^{a}$ (1) \\ aUniversidade Federal do Paraná - UFPR, Zoology Department, Curitiba, Parana, Brasil
}

\begin{abstract}
In fisheries, the phenomenon known as fishing down food webs is supposed to be a consequence of overfishing, which would be reflected in a reduction in the trophic level of landings. In such scenarios, the resilience of carnivorous, top predator species is particularly affected, making these resources the first to be depleted. The Serra Spanish mackerel, Scomberomorus brasiliensis, exemplifies a predator resource historically targeted by artisanal fisheries on the Brazilian coast. The present work analyzes landings in three periods within a 50-year timescale on the Parana coast, Southern Brazil, aiming to evaluate whether historical production has supposedly declined. Simultaneously, the diet was analyzed to confirm carnivorous habits and evaluate the trophic level in this region. Surprisingly, the results show that from the 1970's to 2019 Serra Spanish mackerel production grew relatively to other resources, as well as in individual values. The trophic level was calculated as 4.238, similar to other Scomberomorus species, consisting of a case where landings increase over time, despite the high trophic level and large body size of the resource. The results agree with a recent global assessment that has demystified a necessary correlation between high trophic level and overexploitation, but possible factors acting on the present findings are discussed.
\end{abstract}

Keywords: fishing, overfishing, diet, Scombridae, Brazil.

\begin{abstract}
Resumo
Na pesca, o fenômeno fishing down food webs, ou 'pescando teias tróficas abaixo', expressa a redução do nível trófico na composição das capturas, e tem origem tradicionalmente atribuída à sobrepesca. Sob intenso extrativismo, a resiliência das espécies carnívoras, predadoras de topo, é particularmente afetada, sendo seus estoques os primeiros a entrarem em depleção. A cavala, ou serra, ou sororoca, Scomberomorus brasiliensis, é exemplo de recurso predador historicamente alvo da pesca artesanal, de pequena escala, na costa brasileira. 0 presente trabalho analisa os valores de desembarque do recurso em três períodos ao longo de 50 anos na costa paranaense, sul do Brasil, com objetivo de avaliar se sua produção tem efetivamente diminuído. Ainda, estuda-se a dieta da espécie na região, para confirmar seus hábitos carnívoros e avaliar o nível trófico na região. Os resultados mostram que, surpreendentemente, dos anos 1970 para 2019 a produção de S. brasiliensis tem aumentado em valores absolutos, bem como relativamente à de outros recursos, em que pese o nível trófico 4,238, similar a outras espécies do gênero. Constata-se que a pesca da cavala na região de estudo constitui um caso de aumento nos desembarques a despeito de elevado nível trófico e grande tamanho corpóreo. Os resultados concordam com recente levantamento em nível mundial, que nega existir correlação necessária entre sobrepesca e nível trófico alto, mas fatores que podem explicar os resultados do presente trabalho são discutidos.
\end{abstract}

Palavras-chave: pesca, sobrepesca, nível trófico, cavala, Brasil.

\section{Introduction}

The most valued fisheries resources, and consequently the species preferentially targeted by fishers, are traditionally top predators with larger sizes. In Southern Brazil, the market price of piscivorous resources is approximately $70 \%$ higher than that of non-piscivorous resources (Lecheta et al., 2017). Since the $20^{\text {th }}$ century,

around the world, fish landings of carnivorous resources have been declining due to overexploitation, starting with a search for fish with smaller, shorter life cycles at lower trophic levels (Pauly et al., 1998). However, fishing down food webs are not unanimous, and several authors consider that overfishing does not necessarily explain the lower

*e-mail: ptchaves@ufpr.br

Received: December 2, 2020 - Accepted: March 9, 2021 
trophic level in landings. For example, Essington et al. (2006) confirmed fishing down food webs in the Tropical Atlantic ecosystem and five other oceanographic regions, but with no trends indicating its relatioships to overexploitation of higher carnivores. Pershing et al. (2014) studied diet changes in marine resources and discarded a top-down origin, citing invasions of gelatinous plankton (Aurelia aurita and others) as the main cause of changes in the trophic web in the Black Sea. Even so, these authors admitted that a decline in predator abundance could provoke a cascade effect, affecting the attainement of the base of the trophic web. A good example is the Cod fishery in the Baltic Sea.

Should we expect a decline in the top predator species in Brazilian coastal landings, representing a top-down fishing pressure? Alternatively, can stability in landings be associated with changes in species' diet and reduction in the trophic level?

The present work focuses on the Serra Spanish mackerel (Scomberomorus brasiliensis Collete, Russo \& Zavala Camin, 1978), a carnivorous species caught on the Brazilian coast. Locally known as cavala, serra, or sororoca, this species is commonly targeted using gillnets (Fonteles-Filho, 1988; Batista and Fabré, 2001), and their landings are continuous throughout the year in Southern Brazil (Chaves and Robert, 2003; Andriguetto-Filho et al., 2006; Chaves and Silva, 2019). This species' maximum length has exceeded $1.0 \mathrm{~m}$, but the length of the fish for commercial fishing was between 50 and $70 \mathrm{~cm}$. Scomberomorus brasiliensis is sympatric with $S$. cavalla and has been mistaken as the Central American S. maculatus (Dias-Neto and Dias, 2015), which does not inhabit Brazilian waters. In Venezuela and Northwest Brazil, S. brasiliensis feeds on small fish, crustaceans and mollusks (Menezes, 1970;
Vasconcelos-Filho et al., 1984; Bashirullah and Acuña, 1988). The trophic level was calculated as 3.3 by considering the northwest coast of Brazil (Vasconcelos-Filho et al., 1984; Vasconcellos and Gasalla, 2001). However, the trophic level of some Scomberomorus species reaches 4.5, such as S. cavalla and S. maculatus in the Gulf of Mexico (Finucane et al., 1990), and S. semisfasciatus in Australia (Salini et al., 1998). This work aimed to evaluate the production values of $S$. brasiliensis over 50 years in a study region in Southern Brazil, and discuss them in view of the trophic level of this species.

\section{Material and Methods}

The study used the historical database on the landings of Serra Spanish mackerel in Matinhos locality, Paraná state, Southern Brazil. Small-scale fisheries act on a fishery zone around 2530'S; 48ํW (Figure 1), summing approximately 70 boats, as described by Chaves and Robert (2003). Values refer to three periods: 1970-1974 (Loyola-e-Silva and Nakamura, 1975); 1991-1994 (Brasil, 1995); and 2017-2019 (FUNDEPAG, 2020). In the first two periods, the resource was generically cited as 'cavala', misleading Scomberomorus brasiliensis and S. cavalla. The third period refers exclusively to $S$. brasiliensis. In all periods, the annual values were considered individually. Monthly values were available for the last two periods, and they showed how heterogeneous production occurs throughout the year.

The diet of $S$. brasiliensis was obtained from samples collected from March 2020 to June 2020 in the Matinhos landings. This species was caught using gillnets at depths of approximately $15 \mathrm{~m}$ and latitudes of $25-26^{\circ} \mathrm{S}$, which were mainly close to two islands, Currais and

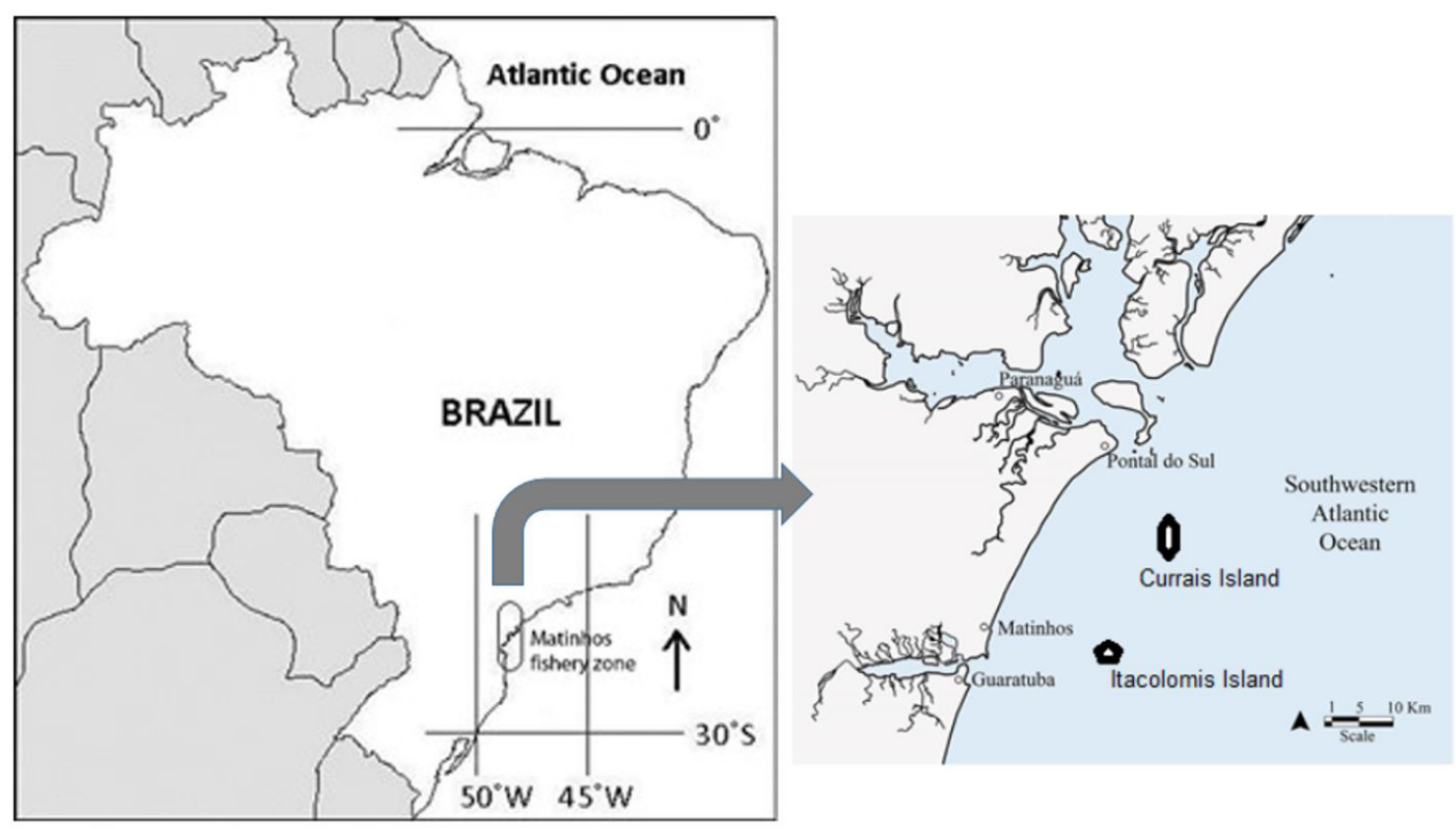

Figure 1. Map indicating Matinhos fishery zone (2530' S; 48’ W), and Currais and Itacolomis Islands, in the Brazilian coast, Southwestern Atlantic Ocean. 
Itacolomis (Figure 1). After landing, the fork length (FL) of the specimens was obtained, and their stomachs were extracted and fixed in $10 \%$ formalin. In the laboratory, the stomach contents were filtered, and the retained fraction was weighed. All contents were then determined under a microscope and grouped according to the prey category. Each prey item was weighed, and the number of structures representing each prey was recorded.

\subsection{Data processing}

Landing is presented in absolute and relative values, and the total catches including crustaceans and mollusks.

A total of 74 specimens, FL $250-670 \mathrm{~mm}$, had stomach content recognized (Figure 2). Structures were grouped by prey number, and the mass of the preys were processed using three methods (Pinkas et al., 1971):

(1) Frequency of Occurrence: $\mathrm{FOi}=\mathrm{Ni} / \mathrm{N} * 100$, where $\mathrm{Ni}$ is the number of stomachs containing prey ' $\mathrm{i}$ ' and $\mathrm{N}$ the number of stomachs where a prey was identified;

(2) Numerical Importance: \% $\mathrm{Ni}=\mathrm{Ni} / \mathrm{N} * 100$, where $\mathrm{Ni}$ is the number of preys ' $i$ ' in all stomachs summed, and $\mathrm{N}$ the sum of all preys, all stomachs considered; and

(3) Relative Biomass: \% $\mathrm{Bi}=\mathrm{Bi} / \mathrm{B} * 100$, where $\mathrm{Bi}$ is the total mass of prey ' $i$ ', preys individually weighed, and $B$ the sum of the mass of all preys, all stomachs considered.

These results were assembled to calculate the Relative Importance Index, by prey 'i': RIIi $=(\% \mathrm{Ni}+\% \mathrm{Bi}){ }^{*} \mathrm{FOi}$, adapted from Pinkas et al. (1971) replacing volume by mass.

Finally, the trophic level was estimated as $\mathrm{TL}=\Sigma(\mathrm{Bi}$ $\left.{ }^{*} \mathrm{TLi}\right)+1$, where $\mathrm{Bi}$ is the relative contribution of prey in mass, and TLi is the trophic level of such prey. In order to improve the accuity in the study, the TL values for prey were imported from Cortés (1999), who assembled data on shark prey to estimate the TL values in shark species.

\section{Results}

\subsection{Landings retrospective}

Historical data indicated an important growth in the Serra Spanish mackerel landings from 1970-1974 to 2017-2019. During the first period, the annual production increased from 0.4-74.7 t (Scomberomorus brasiliensis + S. cavalla) to $45.5-89.2 \mathrm{t}$ (S. brasiliensis) in the second period. During an intermediary period (1991-1994) the summed annual production of the two species varied between 4.1-13.6 t. Additionally, S. brasiliensis landings increased over the last three years: $45.5 \mathrm{t}$ in 2017, $52.4 \mathrm{t}$ in 2018 , and $89.1 \mathrm{t}$ in 2019 (Figure 3).

The relative participation of Scomberomorus in the total production of Matinhos increased from $0.6-8.4 \%$ in $1970-1974$, and $5.4-15.3 \%$ in $1991-1994$, to $32.8-37.9 \%$ in 2017-2019 (Figure 3).

The production throghouth the year was not uniform. Peaks higher than $30 \%$ of the total catch per year were registered in autumn months (1991-1994) and winter months (2017-2019), while the period from any month in

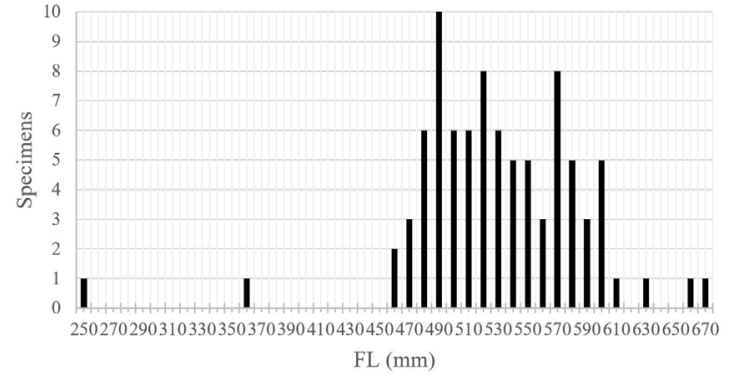

Figure 2. Number of Scomberomorus brasiliensis specimens landed by Matinhos fleet from March to June 2020 and studied respect to diet, according to the fork length (FL) class.

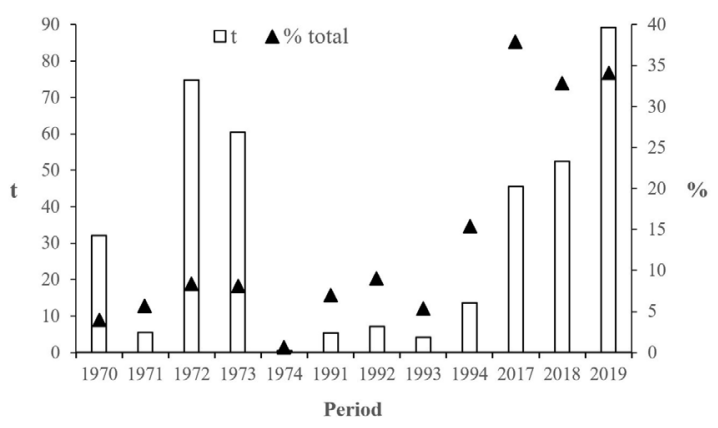

Figure 3. Annual landings of Scomberomorus species (1970-1973 and 1991-1994) and of S. brasiliensis (2017-2019) (t), and relative participation in fishery total landings (\%) in Matinhos, Southern Brazil. Data sources: 1970-1974: Loyola-e-Silva and Nakamura (1975); 1991-1994: MMA/IBAMA (Brasil, 1995); and 2017-2019: FUNDEPAG (2020).

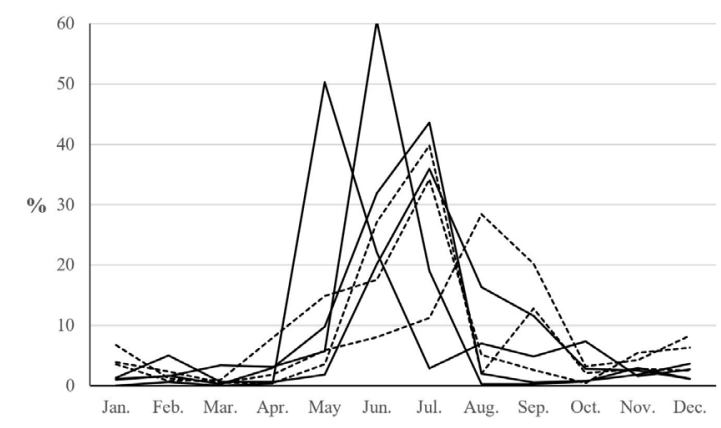

Figure 4. Monthly values of $S$. brasiliensis landings per month, relative (\%) to total landing per year, in Matinhos, Southern Brazil. Solid lines: 1991-1994 period; dotted lines: 2017-2019 period. Data source: MMA/IBAMA (Brasil, 1995) and FUNDEPAG (2020).

October to April accounted for less than $10 \%$ of the annual production (Figure 4).

\subsection{Diet}

Three prey groups were found: 'fish' Frequency of Occurrence 100\%; Proboscis worms "Nemertea" $12.2 \%$, and 'squids' $5.4 \%$. The last two prey items only occurred in May 
and June, with a FO inferior to 25\% (Table 1). Furthermore, $40.5 \%$ of the stomachs had parasites.

The most common structure observed in prey 'fish' was crystalline lenses, which could number up to 59 in a single stomach. Otoliths, vertebral column, cycloid scales, and two types of ctenoid scales were also common. Other recognized fish structures were the head, tail and fins. The size of the heads and vertebral columns, which were about 0.5 to $7 \mathrm{~cm}$ long, indicated that the fish ingested were small in size, with 30 vertebrae in a $4 \mathrm{~cm}$ extension and the mouth of the prey fish in a superior position. In some stomachs, fish were mixed with small bivalves $(1 \mathrm{~mm})$. Concerning the prey 'Nemertea' the body was sometimes almost complete but displayed evidence of digestion, indicating that it was not a parasite. Among 'squids' the radula of Ornithoteuthis antillarum and Hyaloteuthis pelagica were identified (Table 2).

In order to calculate the numerical importance (\%Ni), the number of vertebral columns, or the number of pairs of crystalline, or each of the three pairs of otoliths (the highest value between them) found in stomach contents indicated the number of fish ingested. Ctenoid plus cycloid scales in the stomach indicated a minimum of two fish ingested; each part of a Proboscis worm indicated one Nemertea, and each radula corresponded to one squid (Table 1 ). The \%Ni values obtained were: $94.57 \%$ for fish, $3.99 \%$ for Nemertea and $1.45 \%$ for squids.

In order to calculate relative biomass, all prey structures were considered, resulting in the following values: $99.24 \%$ for fish, $0.27 \%$ for Nemertea and $0.49 \%$ for squids.

Therefore, the Relative Importance Index has resulted in 188.37 for fish, 1.00 for Nemertea and 0.18 for squid, and the relative participation of prey in the diet of $S$. brasiliensis was $99.68 \%, 0.27 \%$ and $0.05 \%$, respectively.
Finally, the following TLi values were used to calculate the trophic level: 3.24 for fish: vertebral columns showed that they were teleosts; 2.5 for Nemertea, also following Cortés (1999); according to McDermott and Roe (1985), most of Nemertea have carnivorous habits; and 3.2 for Hyaloteuthis pelagica and Ornithoteuthis antillarum: these two squids feed on cephalopods, benthic and planktonic crustaceans, and worms (Palomares and Pauly, 2020; Arkhipkin et al., 1998, respectively). The trophic level of S. brasiliensis was 4.238 (Table 3 ).

\section{Discussion}

Commercial catch assessments must be done with caution. Many captures have not been reported, and because of the periodical turnover in fishing techniques, changes in landings do not necessarily reflect fish abundance (Pauly et al., 2013). The accuracy of the data is also limited when sampling methods change over time, which probably occurred in the present assessment. Even so, it was unequivocal to observe growth in S. brasiliensis landings with respect to total fishery production. Moreover, while the first two periods accounted for two Scomberomorus species together, the third period considered only S. brasiliensis. These facts highlight the role played by Serra Spanish mackerel in catches, performing better in 2017 to 2019 compared to the 70's and 90's.

Increased landings from 2017 to 2019 do not necessarily reflect the availability of this resource. These landings can be a result of higher fishery effort/efficacy by Matinhos fleet, including fishing gear and fishing areas; and/or low availability of other pelagic resources. The decline in mullet catches (Mugil liza) since the 2000s is one example; its catch increased due to purse seines fishing in Southern Brazil, and

Table 1. Number of specimens ( $\mathrm{n}$ ) of S. brasiliensis which stomach contents was recognized; fork length range (FL) of specimens; minimum-maximum number of prey units by stomach; and Frequency of Occurrence by prey (FO).

\begin{tabular}{ccccccccc}
\hline & \multirow{2}{*}{} & \multirow{2}{*}{ FL (mm) } & \multicolumn{6}{c}{ Preys: number by stomach and occurrence } \\
\cline { 4 - 8 } & & & Fish & Fo & Nemertea & Fo & Squids & Fo \\
\hline March & 23 & $470-580$ & $1-30$ & $100 \%$ & 0 & 0 & 0 & 0 \\
April & 17 & $250-600$ & $1-7$ & $100 \%$ & 0 & 0 & 0 & 0 \\
May & 23 & $460-600$ & $1-7$ & $100 \%$ & 1 & $22.7 \%$ & 1 & $4.5 \%$ \\
June & 24 & $360-670$ & $1-8$ & $100 \%$ & $1-3$ & $18.2 \%$ & 1 & $13.6 \%$ \\
\hline
\end{tabular}

Table 2. Structures identified in stomach contents of S. brasiliensis according to prey: estimated prey number (N); percentage of stomachs where structures corresponding to such prey were present (\%); mean number of stomachs structures by stomach (n); and fork length range of specimens (FL). Scales, tail and head of fish are omitted.

\begin{tabular}{cccccc}
\hline Prey & $\mathbf{N}$ & Structure & Stomach $\%$ & n (mean) & FL range $(\mathbf{m m})$ \\
\hline Fish & 87 & Crystalline & 64.4 & 4.8 & $250-670$ \\
& & Column & 33.3 & 0.8 & \\
& & Otolith & 9.2 & 0.2 & $460-600$ \\
Nemertea & 6 & Body & 100.0 & 1.0 & $460-600$ \\
Squids & 4 & Radula & 100.0 & 1.2 & \\
\hline
\end{tabular}


Table 3. Values of Relative Biomass (\%Bi), trophic level by prey (TLi), and resulting value of trophic level of $S$. brasiliensis.

\begin{tabular}{cccc}
\hline Prey & \%Bi & TLi & Bi $^{*} \mathbf{T L i}$ \\
\hline Fish & 99.24 & 3.24 & 3.215 \\
Nemertea & 0.27 & 2.5 & 0.007 \\
Squids & 0.49 & 3.2 & 0.016 \\
& $\mathbf{T L}=\mathbf{\Sigma}\left(\right.$ \%Bi $\left.^{*} \mathbf{T i}\right)+\mathbf{1}$ & 4.238 \\
\hline
\end{tabular}

affected small-scale fisheries (Herbst and Hanazaki, 2014; Abreu-Mota et al., 2018). They shifted attention to other targets such as mackerel, with emerged due to the loss in stock of mullet. Unfortunately, the data on the individual's length and weight are not available to compare with the three periods the present study considered to evaluate possible changes in catch selectivity.

Data on feeding habits only referred to four months, which neglected the possible role played by algae, cnidarians, and mollusks in other seasons. This possibility was reinforced by the fact that these items, together with fish, worms, and squids, comprise the diet of $S$. brasiliensis in Northeast Brazil (Menezes, 1970; FontelesFilho, 1988). Depending on availability, carnivorous species can add invertebrates to a diet based on fish; this is supported by observations of Winemiller (1989) in nine freshwater species, and by Hanson and Chouinard (2002) and Hall-Scharf et al. (2016) in cod and weakfish, respectively. The absence of invertebrates other than Nemertea and squid explains the high estimated trophic level for S. brasiliensis. It is similar to the average value of 4.2 cited by Cortés (1999) for scombrids, which is lower than 4.5 calculated for S. cavalla and S. maculatus in the Gulf of Mexico (Finucane et al., 1990), and higher than 3.6-3.8 in 'bentho-pelagic and large bentho-pelagic fishes' from the southeastern Brazilian bight (Nascimento et al., 2012), or 3.3 in S. brasiliensis from the northeast coast (Vasconcelos-Filho et al., 1984). However, the trophic level value that Vasconcelos-Filho et al. (1984) obtained for $S$. brasiliensis included estuarine juvenile specimens in their analysis.

The most common structure found in the samples is crystalline lenses. The size diversity of vertebral columns and crystalline lenses indicates that different sizes of fish, such as juveniles, adults, and/or different fish species, were ingested. This possibility was strengthened owing to findings ctenoid and cycloid scales within the same stomach content. Taking into account the scale shape, S. brasiliensis feeds on at least three species of fish. The mouth position of the prey's heads indicates they may be surface feeders that probably feed on small bivalves. Nemertea, with 45 species on the Brazilian coast (Mendes et al., 2016), is a food source for at least 27 fish species in the Northwest Atlantic, and it is also used as live bait for fishing off the coast of Africa (McDermott, 2001). Nematode worms, but not Nemertea, were determined to be part of the diets of S. brasiliensis and S. maculatus in the Northeast Brazilian coast and the Gulf of Mexico, respectively (Vasconcelos-Filho et al., 1984; Finucane et al., 1990). Squid predation is well known in Scombridae (Gorni et al., 2013). It includes the Scomberomorus species (Vasconcelos-Filho et al., 1984; Finucane et al., 1990), and S. brasiliensis (Loliginidae, pelagic - Fonteles-Filho, 1988). Hyaloteuthis pelagica and Ornithoteuthis antillarum are commonly found in the guts of tuna, swordfish and birds on the Brazilian coast (Vasque-Junior, 2005; Cherel et al., 2007), including Southern Brazil (Santos and Haimovici, 2002), but none of these studies cited ingestion by S. brasiliensis.

It has been argued that mackerels show an inherent resilience to overfishing, which Juan-Jordá et al. (2011) attributed to their fast-growing, early-maturing, and short lifespan. In some areas in Northern Brazil S. brasiliensis fisheries were considered as collapsed (Almeida et al., 2011), but the collapse of a fishery resource is not necessarily a consequence of trophic restrictions. Gaichas et al. (2015) showed that control mechanisms (top-down, bottom-up, mixed) vary between ecosystems, resulting in different responses to fishery resources. This is the case when comparing the Bering Sea and Gulf of Alaska, where food web structures differ when viewed from the perspective of the walleye pollock, Gadus chalcogrammus (Gaichas et al., 2015). In fact, a global assessment by Pinsky et al. (2011) has demystified a necessary correlation between high trophic levels and overexploitation. Among top predators, those with trophic level $>4.2$ have collapsed in only $12 \%$ of stocks around the world, while low trophic-level resources $<3.3$ have collapsed up to $25 \%$.

The Serra Spanish mackerel in Matinhos, trophic level 4.238, exemplifies a case where landings have increased over time, despite the high trophic level of this resource. The effect this fact plays on the trophic level of local fisheries remains unknown. Potentially, it is similar to that described by Vasconcellos and Gasalla (2001) in Southern Brazil during the late 1980's and early 1990's, when the important catches of tuna and shark, and the collapse of the Brazilian sardine, lead to an increase in the mean trophic level of fisheries (from 2.8 to 3.1). It highlights the importance of continuous assessments on fishery dynamics in Brazilian coast, evaluating biomass, effort, landings, and the life history traits of resources, a basis for fisheries management.

\section{Acknowledgements}

Authors gratefully thank to Dr. Rodrigo Medeiros (UFPR), to Matinhos fishers, and to BJB Referees, for their help in achievement of this work.

\section{References}

ABREU-MOTA, M.A., MEDEIROS, R.P. and NOERNBERG, M.A., 2018. Resilience thinking applied to fisheries management: perspectives for the mullet fishery in Southern-Southeastern Brazil. Regional Environmental Change, vol. 11, no. 7, pp. 20472058. http://dx.doi.org/10.1007/s10113-018-1323-9.

ALMEIDA, Z.S., ISAAC, V.J., SANTOS, N.B. and PAZ, A.C., 2011. Sustentabilidade dos sistemas de produção pesqueira maranhense. In: M. HAIMOVICI, ed. Sistemas pesqueiros marinhos 
e estuarinos do Brasil: caracterização e análise da sustentabilidade. Rio Grande: Ed. da FURG, pp. 25-40.

ANDRIGUETTO-FILHO, J.M., CHAVES, P.T., SANTOS, C. and LIBERATI, S.A., 2006. Diagnóstico da pesca no litoral do estado de Paraná. In: V.N. ISAAC, M. HAIMOVICI, S.A. MARTINS and J.M. Andriguetto, eds., A pesca marinha e estuarina do Brasil no início do século XXI: recursos, tecnologias, aspectos socioeconômicos e institucionais. Belém: Universidade Federal do Paraná, pp. 117-140.

ARKHIPKIN, A.I., LAPTIKHOVSKY, V.V., NIGMATULLIN, C.M., BESPYATYKH, A.V. and MURZOV, S.A., 1998. Growth, reproduction and feeding of the tropical squid Ornithoteuthis antillarum (Cephalopoda, Ommastrephidae) from the centraleast Atlantic. Scientia Marina, vol. 62, no. 3, pp. 273-288.

BASHIRULLAH, A.K.M. and ACUÑA, A.C., 1988. Analisis del contenido estomacal del carite pintado, Scomberomorus brasiliensis Collette, Russo y ZavalaCamin, 1978 en el oriente de Venezuela. Boletim do Instituto Oceanográfico, vol. 27, no. 1-2, pp. 117-122.

BATISTA, V.S. and FABRÉ, N.N., 2001. Temporal and spatial patterns on serra, Scomberomorus brasiliensis (Teleostei, Scombridae), catches from fisheries on the Maranhão coast, Brazil. Brazilian Journal of Biology = Revista Brasileira de Biologia, vol. 61, no. 4, pp. 541-546. http://dx.doi.org/10.1590/S1519-69842001000400003. PMid: 12071310.

BRASIL. MINISTÉRIO DO MEIO AMBIENTE, DOS RECURSOS HÍDRICOS E DA AMAZÓNIA LEGAL. INSTITUTO BRASILEIRO DO MEIO AMBIENTE E DOS RECURSOS NATURAIS RENOVÁVEIS IBAMA, 1995 [viewed 24 September 2020]. Estatística da Pesca 1991/1992/1993/1994: Brasil grandes regiões e unidades da Federação. Tamandaré (PE) [online]. Brasília: ICMBio. Available from: www.icmbio.gov.br/cepsul/biblioteca/acervo-digital/38download/artigos-cientificos/112-artigos-cientificos.html

CHAVES, P.T.C. and ROBERT, M.C., 2003. Embarcações, artes e procedimentos da pesca artesanal no litoral sul do estado do Paraná, Brasil. Atlântica, vol. 25, no. 1, pp. 53-59.

CHAVES, P.T.C. and SILVA, A.V.F., 2019. Recursos-alvo que são também bycatch, e recomendação para a gestão da pesca de emalhe no litoral do Paraná, Brasil. Biodiversidade e Conservação Marinha, vol. 8, pp. 1-11.

CHEREL, Y., SABATIÉ, R., POTIER, M., MARSAC, F. and MÉNARD, F., 2007. New information from fish diets on the importance of glassy flying squid (Hyaloteuthis pelagica) (Teuthoidea: Ommastrephidae) in the epipelagic cephalopod community of the tropical Atlantic Ocean. Fish Bulletin, vol. 105, no. 1, pp. 147-152.

CORTÉS, E., 1999. Standardized diet compositions and trophic levels of sharks. ICES Journal of Marine Science, vol. 56, no. 5, pp. 707-717. http://dx.doi.org/10.1006/jmsc.1999.0489.

DIAS-NETO, J. and DIAS, J.F.D., 2015. Uso da biodiversidade aquática no Brasil: Uma avaliação com foco na pesca. Brasília: Ministério do Meio Ambiente, IBAMA, 288 p.

ESSINGTON, T.E., BEAUDREAU, A.H. and WIEDENMANN, J., 2006. Fishing trhough marine food webs. PNAS, vol. 103, no. 9, pp. 3171-3175. http://dx.doi.org/10.1073/pnas.0510964103.

FINUCANE, J.H., GRIMES, C.B. and NAUGHTON, S.P., 1990. Diets of young king and Spanish mackerel off the Southeast United States. Northeast GulfScience, vol. 11, no. 2, pp. 145-153. http:// dx.doi.org/10.18785/negs.1102.07.

FONTELES-FILHO, A.A., 1988. Sinopse de informações sobre a cavala, Scomberomorus cavalla (Cuvier) e a serra, Scomberomorus brasiliensis Collete, Russo \& Zavalla-Camin (Pisces: Scombridae), no estado do Ceará, Brasil. Arquivos de Ciências do Mar, vol. 27, no. $1-2$, pp. 21-48.
FUNDAÇÃO DE DESENVOLVIMENTO DA PESQUISA DO AGRONEGÓCIO - FUNDEPAG, 2020 [viewed 24 September 2020]. Banco de Dados do Monitoramento Pesqueiro do litoral do Paraná [online]. Available from: http://propesq-pr.fundepag. $\mathrm{br} /$ relatorio/30

GAICHAS, S., AYDIN, K. and FRANCIS, R.C., 2015. Wasp waist or beer belly? Modeling food web structure and energetic control in Alaskan marine ecosystems, with implications for fishing and environmental forcing. Progress in Oceanography, vol. 138, no. Pt A, pp. 1-17. http://dx.doi.org/10.1016/j.pocean.2015.09.010.

GORNI, G.R., GOITEIN, R. and AMORIM, A.F., 2013. Descrição da dieta de peixes pelágicos no Oceano Atlântico, Brasil. Biota Neotropica, vol. 13, no. 1, pp. 61-69. http://dx.doi.org/10.1590/ S1676-06032013000100006.

HALL-SCHARF, B.J., SWITZER, T.S. and STALLINGS, C.D., 2016. Ontogenetic and long-term diet shifts of a generalist juvenile predatory fish in an urban estuary undergoing dramatic changes in habitat availability. Transactions of the American Fisheries Society, vol. 145, no. 3, pp. 502-520. http://dx.doi.org/10.1080 /00028487.2016.1143396.

HANSON, J.M. and CHOUINARD, G.A., 2002. Diet of Atlantic cod in the southern Gulf of St. Lawrence as an index of ecosystem change, 1959-2000. Journal of Fish Biology, vol. 60, pp. 902-922. http://dx.doi.org/10.1006/jfbi.2002.189.

HERBST, D.F. and HANAZAKI, N., 2014. Local ecological knowledge of fishers about the life cycle and temporal patterns in the migration of mullet (Mugil liza) in Southern Brazil. Neotropical Ichthyology, vol. 12, no. 4, pp. 879-890. http://dx.doi.org/10.1590/19820224-20130156.

JUAN-JORDÁ, M.J., MOSQUEIRA, I., COOPER, A.B., FREIRE, J. and DULVY, N.K., 2011. Global population trajectories of tunas and their relatives. Proceedings of the National Academy of Sciences of the United States of America, vol. 108, no. 51, pp. 20650-20655. http://dx.doi.org/10.1073/pnas.1107743108. PMid:22143785.

LECHETA, T., AFONSO, M.G. and CHAVES, P.T., 2017. Investigação sobre fishing down marine food webs no sul do Brasil: implicações financeiras e para a sustentabilidade. Arquivos de Ciências do Mar, vol. 50, no. 2, pp. 30-44.

LOYOLA E SILVA, J. and NAKAMURA, I.T., 1975. Produção do pescado no litoral paranaense. Acta Biologica Paranaense, vol. 4, no. 3-4, pp. 75-119.

MCDERMOTT, J. and ROE, P., 1985. Food, feeding behavior and feeding ecology of Nemerteans. American Zoologist, vol. 25, no. 1, pp. 113-125. http://dx.doi.org/10.1093/icb/25.1.113.

MCDERMOTT, J., 2001. Status of the Nemertea as prey in marine ecosystems. Hydrobiologia, vol. 456, no. 1-3, pp. 7-20. http:// dx.doi.org/10.1023/A:1013001729166.

MENDES, C.B., MATTHEWS-CASCON, H. and NORENBURG, J.L., 2016. New records of ribbon worms (Nemertea) from Ceará, Northeast Brazil. Zootaxa, vol. 4061, no. 2, pp. 146-156. http:// dx.doi.org/10.11646/zootaxa.4061.2.4. PMid:27395488.

MENEZES, M.F., 1970. Alimentação da Serra, Scomberomorus maculatus (Mitchill) em águas costeiras do estado do Ceará. Arquivos de Ciências do Mar, vol. 10, no. 2, pp. 171-176.

NASCIMENTO, M.C., VELASCO, G., OKEY, T.A., CHRISTENSEN, V. and AMARAL, C.Z., 2012. Trophic model of the outer continental shelf and upper slope demersal community of the southeastern Brazilian Bight. Scientia Marina, vol. 76, no. 4, pp. 763-779. http://dx.doi.org/10.3989/scimar.03359.26A.

PALOMARES, M.L.D. and PAULY, D., 2020 [viewed 24 September 2020]. SeaLifeBase. Version (07/2020) [online]. Available from: www.sealifebase.org 
PAULY, D., CHRISTENSEN, V., DALSGAARD, J., FROESE, R. and TORRES JUNIOR, F., 1998. Fishing Down Marine Food Webs. Science, vol. 279, no. 5352, pp. 860-863. http://dx.doi.org/10.1126/ science.279.5352.860. PMid:9452385.

PAULY, D., HILBORN, R. and BRANCH, T., 2013. Does catch reflect abundance? Nature, vol. 494, no. 7437, pp. 303-306. http:// dx.doi.org/10.1038/494303a. PMid:23426308.

PERSHING, A.J., MILLS, K.E., RECORD, N.R., STAMIESZKIN, K., WURTZELL, K.V., BYRON, C.J., FITZPATRICK, D., GOLET, W.J. and KOOB, E., 2014. Evaluating trophic cascades as drivers of regime shifts in different ocean ecosystems. Philosophical Transactions of the Royal Society of London. Series B, Biological Sciences, vol. 370, no. 1659, pp. 20130265. http://dx.doi. org/10.1098/rstb.2013.0265.

PINKAS, L., OLIPHANT, M.S. and IVERSON, I.L.K., 1971. Food habits of albacore, Bluefin tuna, and bonito in California waters. California Department of Fish and Game. Fish Bulletin, vol. 152, pp. 105.

PINSKY, M.L., JENSEN, O.P., RICARD, D. and PALUMBI, R., 2011. Unexpected patterns of fisheries colapse in the world's oceans. Proceedings of the National Academy of Sciences of the United States of America, vol. 108, no. 20, pp. 8317-8322. http://dx.doi. org/10.1073/pnas.1015313108. PMid:21536889.

SALINI, J.P., BREWER, D.T. and BLABER, S.J.M., 1998. Dietary studies on the predatory fishes of the Norman River estuary, with particular reference to penaeid prawns. Estuarine, Coastal and Shelf Science, vol. 46, no. 6, pp. 837-847. http://dx.doi. org/10.1006/ecss.1997.0319.

SANTOS, R.A. and HAIMOVICI, M., 2002. Cephalopods in the trophic relations off Southern Brasil. Bulletin of Marine Science, vol. 71, no. 2, pp. 753-770.

VASCONCELLOS, M. and GASALLA, M.A., 2001. Fisheries catches and the carrying capacity of marine ecosystems in southern Brazil. Fisheries Research, vol. 50, no. 3, pp. 279-295. http:// dx.doi.org/10.1016/S0165-7836(00)00217-4.

VASCONCELOS-FILHO, A.L., GUEDES, D.S., GALIZA, E.M.B. and AZEVEDO-ARAÚJO, S., 1984. Estudo ecológico da região de Itamaracá (Pernambuco- Brasil). XXVII. Hábitos alimentares de alguns peixes estuarinos. Trabalhos Oceanográficos da Universidade Federal de Pernambuco, vol. 18, no. 1, pp. 231-260. http://dx.doi.org/10.5914/tropocean.v18i1.2613.

VASQUE-JUNIOR, T., 2005. Cefalópodes oceânicos da Zona Econômica Exclusiva do Nordeste do Brasil. Boletim do Instituto de Pesca, vol. 31, no. 2, pp. 137-146.

WINEMILLER, K.O., 1989. Ontogenetic diet shifts and resource partitioning among piscivorous fishes in the Venezuelan llanos. Environmental Biology of Fishes, vol. 26, no. 3, pp. 177-199. http://dx.doi.org/10.1007/BF00004815. 